\title{
Wood molasses as a preservative for high moisture barley. 1. Preservation and digestibility in pig
}

\author{
PEKKA HUHTANEN \\ Department of Animal Husbandry, University of Helsinki, \\ SF-00710 HELSINKI 71, Finland
}

\begin{abstract}
Wood molasses from sulphite spent liquor was tested as a preservative for high moisture barley. In Exp. 1 wood molasses was applied at levels of 8 and $16 \%$ of barley dry matter (DM). In Exp. 2 an application level of $12 \%$ was compared with AIV II solution used at a level of $3 \mathrm{l} / 1000 \mathrm{~kg}$. Barley was rolled before ensiling and water was added so that the moisture content was $55 \%$ in Exp. 1 and $55-60 \%$ in Exp. 2. Digestibility and nitrogen retention in growing pigs, liveweight $31-81 \mathrm{~kg}$, were determined for dried barley, propionic acidtreated barley and barleys ensiled with AIV II or wood molasses (12\% of barley DM).

In Exp. 1 the application level of $8 \%$ unneutralized wood molasses $(\mathrm{pH} 2)$ was sufficient to prevent deterioration during storage. The preservative effect was based mainly on the acidity provided by organic acids. With the higher level of application the lactic acid content was lower $(\mathrm{P}<0.05)$. In Exp. 2 barley ensiled with neutralized wood molasses had a higher $(\mathrm{P}<0.01)$ lactic and acetic acid content and a lower $\mathrm{pH}$ value $(\mathrm{P}<0.05)$ than barley ensiled with AIV II. Wood molasses decreased protein breakdown during the storage. The effect of DM content on fermentation and proteolysis was greater for AIV II ensiled barley. During the storage the sugar content increased because of starch hydrolysis.

DM, organic matter (OM), NFE and starch digestibilities were lower on diets of barley ensiled with AIV II and wood molasses than on dried barley diet $(\mathrm{P}<0.05)$. OM digestibilities for the diets were $82.2,81.0$ and $85.4 \%$, respectively. The digestibility of barley treated with propionic acid was slightly lower than that of dried barley. No differences were found in nitrogen retention.
\end{abstract}

\section{Introduction}

There has been increasing interest in the use of cereal grains as high moisture grain for livestock. Especially in Finland grain must often be harvested at moisture contents above $20 \%$, and the grain must be dried, stored in sealed containers or treated with chemicals to be preserved.
The main chemical preservatives are organic acids (JonEs et al. 1975), but also formaldehyde (BоTHAST et al. 1976) and mixtures of formaldehyde and organic acids can be used as well (Thomke and Tiden 1973). Alternative chemicals are ammonia (BOTHAST et al. 1975), urea (SснміDT et al. 1978) and sodium hydroxide (ØRSKOv et al. 1979). 
Ensiling is a frequently used method to preserve high moisture grain in Finland. Rolled grain is stored in silos at moisture contents of $45 \%$ and acids or other preservatives are added in amounts of $0.3 \%$. The additives are mainly the same as used in grass ensiling (Poutiainen et al. 1973). Common to all silage making processes is that the high moisture grain undergoes fermentation, with production of acids and ethanol. During the fermentation process, the protein present changes from insoluble form to soluble form, and a part of the protein is degraded to NPN (Prigge et al. 1976). The ammonia $\mathrm{N}$ of the total $\mathrm{N}$ is typically $3-5 \%$ in ensiled barley (Poutiainen et al. 1973). Orth et al. (1962) used molasses as a preservative to stimulate lactic acid fermentation, and SALO (1978) found an unneutralized wood molasses from spent sulphite liquor to be an effective preservative for high moisture barley, oats and Brewers' grain in the laboratory scale experiment.

The objective of this study was to investigate wood molasses as a preservative for high moisture barley and compare it with the widely used preservative AIV II solution. Wood molasses is derived from spent sulphite liquor of birch tree by decreasing the amount of lignosulphonates to one third of the initial content by ultrafiltration. The DM content of the molasses was increased from initial $12-13 \%$ to about $55 \%$ by evaporation. Wood molasses contains about $50 \%$ sugars of DM, of which about $70 \%$ is xylose (SALO 1978). The ration digestibility and nitrogen retention in growing pigs were compared for diets of dried barley, propionic acid treated barley and barleys ensiled with AIV II or wood molasses.

\section{Materials and methods}

\section{Preservation experiment}

Two consecutive preservation experiments were carried out. In Exp. 1 barley was harvested at a moisture content of $40 \%$. It was then either rolled and ensiled in $3 \mathrm{~m}^{3}$ glass fibre silos (Ø $1.4 \mathrm{~m}$ ) after addition of unneutralized wood molasses at levels of 8 (WMB8) or $16 \%$ of barley DM (WMB16) or it was dried (DB). The silos were covered with plastic and pressed $\left(300 \mathrm{~kg} / \mathrm{m}^{2}\right)$. In Exp. 2 barley was harvested at a moisture content of 17$25 \%$. It was stored as in Exp. 1, after the addition neutralized wood molasses at level of $12 \%$ of barley DM (WMB12) or $0.3 \% \mathrm{v} / \mathrm{w}$ of AIV II solution ( $80 \%$ formic acid, $2 \%$ orthophosphoric acid) (AIVB). To increase the moisture content of ensiled barley to $40.0,42.5$ and $45.0 \%$ water was added. Whole barley was dried (DB) or treated with $1 \% \mathrm{v} / \mathrm{w}$ of propionic acid (PAB) for digestibility trials.

After an average 3 months the silos were opened. Barley taken out was weighed, $\mathrm{pH}$ measurements were made immediately and samples were taken for analysis. The DM content was determined by oven heating at $103^{\circ} \mathrm{C}$. Before analysis the samples were vacuum-dried at $50^{\circ} \mathrm{C}$ and milled through a 1-mm screen. The DM contents of the ensiled barleys were corrected according to JARL and Helleday (1948) by adding $80 \%$ of acetic and all the other volatile fatty acids to $\mathrm{DM}$ at $103^{\circ} \mathrm{C}$. The feed analyses were made by standard methods. Ammonia N (McGulLOUGH 1967), lactic acid (PARKer and SumMERSON 1947), sugar (NELSON 1944, modified by SomOGY 1945) and volatile fatty acids (Huida 1973) were determined from pooled samples. The mineral composition in Exp. 2 was determined from pooled samples by atomic absorption spektrophotometry and phosphorus according to TAUSSKY and SHORR (1953). Surface fungal contamination, secondary fermentation and ensiling losses in Exp. 2 were also recorded. The differences were tested by one way analysis of variance and the correlations between quality parameters were calculated.

\section{Experiment with pigs}

A digestibility and nitrogen balance trial was carried out with three castrated Yorkshire 
pigs weighing $31-86 \mathrm{~kg}$, using a total collection method. The experiment was designed as a $3 \times 3$ Latin square to compare DB, AIVB and WMB12. The digestibility of PAB was determined afterwards with the same pigs. DB was milled through a $3-\mathrm{mm}$ screen and the other barleys were rolled. Skim milk powder of $19 \%$ was used as protein supplement. The daily rations were also supplemented with $40 \mathrm{~g}$ mineral mixture (KultaTuotos) and $15 \mathrm{~g}$ vitamin mixture (VitamiiniNasu). The crude protein contents of the diets were $16 \%$. Each period lasted 21 days, with transition, standardization and collection periods of seven days each.

Pigs were kept in metabolic cages, which allowed separate collection of faeces and urine. These were collected twice daily and representative samples were frozen and stored till analysis. Sulphuric acid was added the to urine collection pail to decrease the $\mathrm{pH}$ of urine. The pigs were fed twice daily according to energy standards of PARTANEN (1976). Just before feeding the feed was mixed with water $(1: 2 \mathrm{w} / \mathrm{v})$, and water was given freely after feeding. Feed spillages were collected and subtracted from the given feed. The pigs were weighed before and after the collection period.

DM determinations and feed analyses were made as described above under preservation experiments. The starch content was determined by the method of SALO and SALMI (1968) and the NE and ME values were calculated according to SALo et al. (1982). Results were tested by analysis of variance and the differences between the means by the Tukey-test. PAB was not compared statistically with the other treatments.

\section{Results and discussion}

\section{Preservation experiments}

Chemical compositions of raw materials and ensiled barleys, and also mineral composition in Exp. 2, are presented in Table 1. The DM content of wood molasses averaged $55.0 \%$ overall. The sugar content was $47.3 \%$ in Exp. 1 and $31.6 \%$ in Exp. 2 and the ash content 16.3 and $22.7 \%$, respectively. The VFA contents were fairly high; acetic and propionic acid contents were 5.3 and $5.8 \%$ in Exp. 1 and 7.6 and $0.8 \%$ in Exp. 2. The

Table 1. The composition of dried, acid treated and ensiled barleys.

\begin{tabular}{|c|c|c|c|c|c|c|}
\hline & \multicolumn{3}{|c|}{ Exp. 1} & \multicolumn{3}{|c|}{ Exp. 2} \\
\hline & Barley & WMB8 & WMB16 & Barley & AIVB & WMB12 \\
\hline Dry matter, \% & 60.0 & 56.2 & 54.7 & 76.3 & 57.8 & 53.9 \\
\hline \multicolumn{7}{|l|}{ In dry matter, $\%$} \\
\hline Ash & 3.0 & 3.9 & 4.7 & 3.1 & 3.0 & 3.5 \\
\hline Crude protein & 12.3 & 12.1 & 11.5 & 13.9 & 13.9 & 13.0 \\
\hline Ether extract & 2.2 & 2.6 & 2.4 & 2.5 & 2.6 & 2.7 \\
\hline Crude fibre & 5.9 & 5.5 & 5.2 & 6.1 & 5.9 & 5.7 \\
\hline NFE & 76.5 & 75.9 & 76.2 & 74.4 & 74.6 & 75.2 \\
\hline \multicolumn{7}{|l|}{ Mineral composition } \\
\hline $\mathrm{P}, \mathrm{g} / \mathrm{kg} \mathrm{DM}$ & & & & 4.3 & 4.4 & 3.8 \\
\hline $\mathrm{Ca}, \mathrm{g} / \mathrm{kg} \mathrm{DM}$ & & & & 0.6 & 0.8 & 4.7 \\
\hline $\mathrm{Mg}, \mathrm{g} / \mathrm{kg} \mathrm{DM}$ & & & & 1.3 & 1.3 & 1.1 \\
\hline $\mathrm{K}, \mathrm{g} / \mathrm{kg} \mathrm{DM}$ & & & & 6.2 & 5.8 & 4.7 \\
\hline $\mathrm{Na}, \mathrm{g} / \mathrm{kg} \mathrm{DM}$ & & & & 0.3 & 0.2 & 0.2 \\
\hline $\mathrm{Cu}, \mathrm{mg} / \mathrm{kg} \mathrm{DM}$ & & & & 5.5 & 9.8 & 10.5 \\
\hline $\mathrm{Fe}, \mathrm{mg} / \mathrm{kg} \mathrm{DM}$ & & & & 63 & 75 & 84 \\
\hline $\mathrm{Zn}, \mathrm{mg} / \mathrm{kg} \mathrm{LM}$ & & & & 48 & 48 & 43 \\
\hline $\mathrm{Mn}, \mathrm{mg} / \mathrm{kg} \mathrm{DM}$ & & & & 16 & 14 & 28 \\
\hline
\end{tabular}


average DM content of WMP12 was lower than expected because of water leaking into the grain from plastic presswater containers. $\mathrm{CaCO}_{3}$ used to neutralize wood molasses in WMB12 increased the $\mathrm{Ca}$ content sixfold relative to AIVB. The contents of $\mathrm{Cu}, \mathrm{Fe}$ and Mn were also increased in WMB12.

The lower level of wood molasses in Exp. 1 was sufficient to prevent deteriotion during the storage. The effects of additives on fermentation and protein breakdown during the storage are shown in Table 2 . No differences attributable to the level of wood molasses were observed in $\mathrm{pH}$, levels of acetic and propionic acid and nitrogen solubility. SALO (1978), on the other hand, found nitrogen solubility to decrease with increasing level of wood molasses. Lactic acid content of WMB8 was greater than that of WMB16 (P $<0.05$ ) and preservation was based on the acidity of the molasses. Earlier studies in our laboratory (SALO 1978) have also indicated

Table 2. Changes during storage in barley ensiled with wood molasses or AIV II solution.

\begin{tabular}{|c|c|c|c|c|}
\hline & \multicolumn{2}{|c|}{ Exp. 1} & \multicolumn{2}{|c|}{ Exp. 2} \\
\hline & WMB8 & WMB16 & AIVB & WMB12 \\
\hline $\mathrm{pH}$ & 4.09 & 4.11 & $4.40^{\mathrm{a}}$ & $4.08^{b}$ \\
\hline \multicolumn{5}{|l|}{ In dry matter, $\%$} \\
\hline Sugars & 9.5 & 12.0 & 8.5 & 6.5 \\
\hline Lactic acid & $1.76^{\mathrm{a}}$ & $0.85^{b}$ & $0.93^{\mathrm{c}}$ & $3.73^{\mathrm{d}}$ \\
\hline Acetic acid & 0.74 & 1.04 & $0.18^{c}$ & $0.71^{\mathrm{d}}$ \\
\hline Propionic acid & 1.29 & 1.31 & 0.07 & 0.10 \\
\hline Butyric acid & - & - & 0.001 & 0.001 \\
\hline \multicolumn{5}{|l|}{$\%$ of total $\mathrm{N}$} \\
\hline Soluble N & 51.7 & 50.8 & 42.1 & 40.0 \\
\hline Ammonia $\mathrm{N}$ & 3.9 & 3.3 & 2.6 & 2.7 \\
\hline
\end{tabular}

Means with different letters significantly different: $a, b(P<0.05), c, d(P<0.01)$.

Table 3. Correlations between some quality characteristics of ensiled barley.

\begin{tabular}{|c|c|c|c|c|c|c|c|c|}
\hline & & 1 & 2 & 3 & 4 & 5 & 6 & 7 \\
\hline 1. $\mathrm{DM}$ & $\begin{array}{l}\text { AIVB } \\
\text { WMB12 }\end{array}$ & & & & & & & \\
\hline 2. $\mathrm{pH}$ & $\begin{array}{l}\text { AIVB } \\
\text { WMB12 }\end{array}$ & $\begin{array}{l}.73 \\
.43\end{array}$ & & & & & & \\
\hline 3. Sugars & $\begin{array}{l}\text { AIVB } \\
\text { WMP12 }\end{array}$ & $\begin{array}{l}-.82 \\
-.77\end{array}$ & $\begin{array}{l}-.56 \\
-.02\end{array}$ & & & & & \\
\hline 4. Lactic acid & $\begin{array}{l}\text { AIVB } \\
\text { WMB12 }\end{array}$ & $\begin{array}{r}-.81 \\
.11\end{array}$ & $\begin{array}{l}-.87 \\
-.66\end{array}$ & $\begin{array}{l}.66 \\
.54\end{array}$ & & & & \\
\hline 5. Acetic acid & $\begin{array}{l}\text { AIVB } \\
\text { WMB12 }\end{array}$ & $\begin{array}{l}.90^{* *} \\
.20^{* *}\end{array}$ & $\begin{array}{l}-.87 \\
-.38^{*}\end{array}$ & $\begin{array}{l}.69 \\
.82\end{array}$ & $\begin{array}{l}.96 \\
.55^{*}\end{array}$ & & & \\
\hline 6. Propionic acid & $\begin{array}{l}\text { AIVB } \\
\text { WMP12 }\end{array}$ & $\begin{array}{l}-.42 \\
-.15\end{array}$ & $\begin{array}{r}-.02 \\
.11\end{array}$ & $\begin{array}{l}.37 \\
.27\end{array}$ & $\begin{array}{l}.09 \\
.37\end{array}$ & $\begin{array}{l}.26 \\
.18\end{array}$ & & \\
\hline $\begin{array}{l}\text { 7. Soluble } \mathrm{N} \% \text { of } \\
\text { total } \mathrm{N}\end{array}$ & $\begin{array}{l}\text { AIVB } \\
\text { WMB12 }\end{array}$ & $\begin{array}{l}-.85 \\
-.33^{*}\end{array}$ & $\begin{array}{l}-.71 \\
-.45\end{array}$ & $\begin{array}{l}.75 \\
.72\end{array}$ & $.936^{*}$ & $\begin{array}{l}.90 \\
.86\end{array}$ & $\begin{array}{r}.12 \\
-.05\end{array}$ & \\
\hline $\begin{array}{l}\text { 8. Ammonia } \mathrm{N} \% \text { of } \\
\text { total } \mathrm{N}\end{array}$ & $\begin{array}{l}\text { AIVB } \\
\text { WMB12 }\end{array}$ & $\begin{array}{l}-.86 \\
-.46\end{array}$ & $\begin{array}{l}-.81 \\
-.35\end{array}$ & $\begin{array}{l}.75 \\
.82\end{array}$ & $\begin{array}{l}.84 \\
.59\end{array}$ & $\begin{array}{l}.86 \\
.88\end{array}$ & $\begin{array}{l}.24 \\
.32\end{array}$ & $\begin{array}{l}.86 \\
.80 \\
\end{array}$ \\
\hline
\end{tabular}

Correlations were significant: $\mathrm{IrI}>0.58(\mathrm{P}<0.05)$, $\mathrm{IrI}>0.71(\mathrm{P}<0.01)$, IrI $>0.82(\mathrm{P}<0.001)$.

Correlations were significantly different: ${ }^{*}(\mathrm{P}<0.05),{ }^{* *}(\mathrm{P}<0.01)$. 
lower fermentation rate with increasing level of wood molasses.

In Exp. 2 the more neutralized wood molasses increased lactic acid fermentation. The buffering action of $\mathrm{CaCO}_{3}$ probably encouraged acid production by providing a more suitable environment for continued microbial growth (Merrill 1971, Prigge et al. 1976). WMB12 contained more lactic and acetic acid $(\mathrm{P}<0.01)$ than AIVB and the $\mathrm{pH}$ value was lower $(\mathrm{P}<0.05)$. Both AIVB and WMB12 contained more sugars than the same barley before ensiling. This can be explained by starch hydrolysis during the storage. The same effect has been found in propionic acid-treated corn (HoLmes and BAYLEY 1973). The clearly positive correlation between the sugar and lactic acid contents (Table 3) is further indication of starch hydrolysis during the storage. In grass silage this correlation has been negative (ETTALA et al. 1975). Wood molasses was more effective than AIV II solution in preventing starch hydrolysis during storage, because the sugar content of WMB12 was lower than that of AIVB in spite of the sugar increase during preservation.

There were no differences between additives in preventing proteolysis, but if the different DM content of the barleys is eliminated, the proportion of soluble $\mathrm{N}$ of total $\mathrm{N}$ was lower in WMB12 $(\mathrm{P}<0.05)$. This agrees with the results of SALO et al. (1981). Spent sulphite liquor, which contains more lignosulphonates, was more effective in preventing proteolysis than wood molasses or AIV II solution (Salo et al. 1981). Ammonia and soluble $\mathrm{N}$ values correspond with the values reported by Poutiainen et al. (1973) and SAlo et al. (1981).

With increasing moisture levels the contents of fermentation products and sugar increased and $\mathrm{pH}$ decreased (Table 3). There were also clearly positive correlations between fermentation products. The effect of DM content on lactic and acetic acid fermentation and protein degradation was significantly $(\mathrm{P}<0.01, \mathrm{P}<0.05)$ lower for WMB12 than for AIVB. The smaller effect of DM content on lactic acid fermentation and $\mathrm{pH}$ for WMB12 suggest that with wood molasses the grain can be ensiled at higher DM content, and by that means proteolysis (THYSELIUS 1971, Thornton et al. 1977) and DM losses (BYERs et al. 1971) be decreased. When the grains are ensiled in whole form, slight proteolysis occurs and acid production is less and tends to favour acetic acid (PRIGGE et al. 1976). However, it is recommended that the grain be ensiled in ground or rolled form to minimize risks of high storage losses and aerobic deterioration after opening of the silo (Merrill 1971).

$\mathrm{OM}$, ash and crude protein losses were 3.3, 5.6, and $3.7 \%$ for AIVB and 4.2, 20.5, $5.6 \%$ for WMB12, respectively. The higher moisture content of WMB12 increased the effluent losses. The results agree with those of OrTH et al. (1962), ByERS et al. (1971) and Chandler et al. (1975). In contrast, Poutiainen (1971) recorded DM losses of $7-8 \%$.

Table 4. Chemical composition of experimental feeds.

\begin{tabular}{lrrrrr}
\hline & DB & AIVB & WMB12 & PAB & $\begin{array}{c}\text { Skim milk } \\
\text { powder }\end{array}$ \\
\hline Dry matter, \% & 87.6 & 55.3 & 54.8 & 83.7 & 93.5 \\
Ash & 2.7 & 3.2 & 3.8 & 2.7 & 8.4 \\
Crude protein & 11.1 & 11.9 & 11.2 & 11.5 & 37.4 \\
Ether extract & 2.3 & 2.8 & 2.7 & 2.7 & 1.3 \\
Crude fibre & 5.5 & 5.8 & 5.3 & 5.2 & - \\
NFE & 78.3 & 77.3 & 56.0 & 56.0 & 53.0 \\
Starch & 59.1 & 56.2 & 56.0 & - \\
\hline
\end{tabular}




\section{Experiment with pigs}

The chemical composition of the experimental feeds is presented in Table 4. The starch content of DB was higher than that of AIVB and WMB12 $(\mathrm{P}<0.05)$. The solubility of crude protein in pepsin $-\mathrm{HCl}$ was 87.5 $\%$ for DB, $91.5 \%$ for AIVB and $89.6 \%$ for WMB12.

The digestibilities of the diets are presented in Table 5. The AIVB and WMB12 diets had lower digestibilities for DM, OM, NFE and starch than the DB diet $(P<0.05)$. The digestibility of ether extract was significantly $(\mathrm{P}<0.05)$ lower for the WMB12 diet. ThomKe (1968) and Weissbach and SchadeREIT (1968) did not find any significant differences in the digestibility of dried and ensiled rolled grain. The lower starch digestibility for AIVB and WMB12 diets in present experiment indicates that not every grain was thoroughly flattened in rolling. HoLmes and BAYLEY (1973), using fistulated pigs, found slightly lower digestibility of DM, starch and nitrogen for dried than for ensiled corn. AL Chalabi et al. (1974) reported decreased live weight gain at a wood molasses level of $10 \%$ of the diet and NÄsI (1984) found wood molasses at 10-20\% level to decrease DM,
$\mathrm{OM}$ and NFE digestibilities. At higher levels of wood molasses, also protein utilization tended to decrease.

A slightly lower digestibility of PAB than of DB agrees with the results of JUST et al. (1981) and Pringle et al. (1983). THOMKE and TIDEN (1973), on the other hand, reported significantly lower digestibilities for acid treated barley than for dried barley. In the present experiment the digestibility of PAB was determined in heavier pigs, which may have improved the digestibility (Rотн and KirChgessner 1984). Acid treated high moisture barley has, on DM basis, feeding value equal to dried barley according to $\mathrm{LI}$ vingstone et al. (1973), MAdSEn et al. (1973) and Alaviuhrola (1973). But English et al. (1971) and Thомке and TiDen 1973) observed poorer performance on acid-treated barley diets. Alaviuhrola (1973) found no differences in performance of pigs fed on ensiled and dried barley diets, but PARTANEN (1969) found decreased feed utilization in pigs on ensiled barley.

Because of the lower digestibilities calculated NE and ME values were lower for ensiled barleys $(\mathrm{P}<0.05)$. There were no significant differences in DCP values between treatments.

Table 5. Digestibility of the diets, nitrogen retention and calculated feed values of barleys.

\begin{tabular}{|c|c|c|c|c|c|c|c|c|}
\hline & \multicolumn{2}{|c|}{ DB } & \multicolumn{2}{|c|}{ AIVB } & \multicolumn{2}{|c|}{ WMB12 } & \multicolumn{2}{|c|}{ PAB } \\
\hline & $\overline{\mathbf{x}}$ & s.d. & $\overline{\mathbf{x}}$ & s.d. & $\bar{x}$ & s.d. & $\bar{x}$ & s.d. \\
\hline \multicolumn{9}{|l|}{ Digestibility, \% } \\
\hline Dry matter & $83.6^{\mathrm{a}}$ & 1.6 & $80.5^{b}$ & 1.5 & $78.8^{b}$ & 1.5 & 82.9 & 0.2 \\
\hline Organic matter & $85.4^{\mathrm{a}}$ & 1.4 & $82.2^{b}$ & 1.3 & $81.0^{b}$ & 1.3 & 84.7 & 0.1 \\
\hline Crude protein & 82.0 & 2.9 & 81.5 & 2.5 & 79.9 & 1.7 & 80.2 & 0.6 \\
\hline Ether extract & $78.3^{\mathrm{a}}$ & 5.3 & $77.8^{\mathrm{a}}$ & 1.9 & $68.8^{b}$ & 2.7 & 72.6 & 3.8 \\
\hline Crude fibre & 17.3 & 11.7 & 15.4 & 5.7 & 12.3 & 7.2 & 15.4 & 4.6 \\
\hline NFE & $90.4^{a}$ & 0.8 & $87.1^{b}$ & 0.7 & $85.7^{b}$ & 1.1 & 90.0 & 0.0 \\
\hline Starch & $99.1^{\mathrm{a}}$ & 0.1 & $97.3^{\mathrm{b}}$ & 0.7 & $96.9^{b}$ & 0.3 & 99.2 & 0.0 \\
\hline $\mathrm{N}$ retention, $\mathrm{g} / \mathrm{d}$ & 25.5 & & 24.7 & & 25.1 & & 25.7 & \\
\hline \multicolumn{9}{|l|}{ Feed values } \\
\hline $\mathrm{FU} / \mathrm{kg} \mathrm{DM}$ & $1.12^{\mathrm{a}}$ & 0.02 & $1.07^{\mathrm{b}}$ & 0.02 & $1.04^{b}$ & 0.02 & 1.11 & 0.00 \\
\hline $\mathrm{ME} \mathrm{MJ} / \mathrm{kg} \mathrm{DM}$ & $14.6^{\mathrm{a}}$ & 0.3 & $14.0^{b}$ & 0.3 & $13.5^{c}$ & 0.3 & 14.5 & 0.0 \\
\hline DCP g/kg DM & 78 & 8 & 84 & 7 & 74 & 2 & 77 & 1 \\
\hline
\end{tabular}

$\mathrm{FU}=0.7 \mathrm{~kg}$ starch.

Means with different letters were significantly different: $a, b, c(P<0.05)$. 
The increased protein solubility did not have an adverse effect on protein utilization (Table 5). Just et al. (1981) reported $10 \%$ lower nitrogen retention for propionic acidtreated than for dried barley. In the present experiment the protein intake of $120 \mathrm{~g} / \mathrm{FU}$ did not exceed the Finnish standards presented by Salo et al. (1982). At a lower level of protein intake, however, the high content of soluble nitrogen in ensiled barley might have a negative effect on protein utilization by pig.

The results indicate that wood molasses can be used as a preservative of high mois- ture barley. The levels of $8-12 \%$ of barley DM were adequate to prevent deterioration during storage. Wood molasses was also more effective than AIV II solution in preventing aerobic deterioration after opening of the silo. The digestibility trial suggest that barley should be thoroughly flattend before ensiling. A feeding trial is now needed to evaluate the feeding value for pigs of barley ensiled with wood molasses.

Acknowledgements. I wish to express my warm thanks to Mrs. Eija Helander and to Mr. Matti Järvi for their assistance with the experiments.

\section{References}

Alavihkola, T. 1973. Säilöviljaa sioille. Käyt. Maam. 1973, 8: 40-41.

Al-Chalabi, K., Schneider, W., Lantschand, K.H. \& MENKE, K.H. 1974. Futterwert von Holzzuckermelasse in Rationen für Schafe, Schweine und Mastküken Lantwirtsch. Forsch. 27: 1-7.

Barker, S.B. \& Summerson, W.H. 1941. The colorimetric determination of lactic acid in biological material. J. Biol. Chem. 138: 535-554.

Bothast, R.J., Adams, G.H., Hatfield, E.E. \& Lan. CASTER, E.B. 1975. Preservation of high-moisture corn: A microbiological evaluation. J. Dairy Sci. 58: 386-391.

—, Black, L.T., Wilson, L.L. \& Hatfield, E.E. 1976. Methylene-bis-propionate as a preservative of high moisture corn. J. Anim. Sci. 46: 486-489.

Byers, F.M., Goodrich, R.D., Piesson, D.C. \& Meisske, J.C. 1971. Fermentation studies with high-moisture grain. J. Anim. Sci. 33: 378. (Abstr.).

Chandler, P.T., Miller, C.N. \& Jane, E. 1975. Feeding value and nutrient preservation of high moisture corn ensiled in conventional silos for lactating dairy cows. J. Dairy Sci. 58: 682-688.

English, P.R., Topps, J.H. \& Demster, D.G. 1973. Moist barley preserved with propionic acid in the diet of growing pigs. Anim. Prod. 17: 75-83.

Ettala, E., Рohjanheimo, O., Huida, L. \& Lampila, M. 1975. Hapot sekă hapon ja formaldehydin seokset ruohon săilönnässä. I Săilöntătulokset. Kotielăinhoidon tutkimuslaitoksen tiedote 1: 1-27.

Holmes, J.H.G. \& Balley, H.S. 1973. Digestion and absorption of dry and high moisture maize diets in small and large intestine of the pig. Br. J. Nutr. 30: $401-410$.
HuIDA, L. 1973. Haihtuvien rasvahappojen kvantitatiivinen măărittäminen pötsinesteestả. J. Scient. Agric. Soc. Finl. 45: 483-488.

JarL, F. \& Helleday, T. 1948. Ensileringsförsök och utfodringsförsök med ensilage. II Sta. Husd. Förs. Medd. 37: 1-63.

Jones, G.M., Mowat, D.N., Elllot, J.I. \& Moran, E.T., Jr. 1974. Organic acid preservation of high moisture corn and other grain and the nutritional value: A review. Can. J. Anim. Sci. 54: 499-517.

Just, A., Jorgensen, H., Fernandez, J., Jacobsen, E.E. \& Skov-Larsen, C. 1981. Byggens fördojlighet og fodervärdi. Stat. Husd.br.fors. Medd. 348.

Livingstone, R.M., Denerley, H., Stewart, C.S. \& ELSLEY, F.W.H. 1971. Moist barley for growing pigs: some effects of storage method and processing. Anim. Prod. 13: 547-556.

Madsen, A., Mortensen, H.P., Larsen, A.E., Laur. SEn, B. \& Keller Nielsen, E. 1973. Moist barley preserved with propionic acid in the diet for bacon pig. Beretn. Forsøgslab. 407: 1-63. København.

McCullough, H. 1967. The determination of ammonia in whole blood by direct colorimetric method. Clin. chem. Acta 17: 297-309.

Merrill, W.G. 1971. Feeding high moisture grain silages. Proc. Int. Silage Res. Conf. Washington D.C. p. $156-219$.

Nelson, N. 1944. A photometric adaptation of the Somogyi method for the determination of glucose. $\mathbf{J}$. Biol. Chem. 153: 375-380.

NĀsı, M. 1984. Trämelass som svinfoder. NJF Seminarium Nr. 57. 29.-30. 3. 1984. Stenhamra. Sverige. $6 \mathrm{p}$.

Ørskov, E.R., Stewart, C.S. \& Greenhalgh, J.F.D. 
1979. The effect of sodium hydroxide and urea on some storage properties of moist grain. J. agric. Sci., Camb. 92: 185-188.

Orth, H.A., Kaufman, W. \& Косн, G. 1962. Versuche zur Silierung von Getreide. Das wirtschaftseigene Futter 8: $127-136$.

PARTANEN, J. 1969. Tuoreena säilötty vilja teruassikojen rehuna. MTTK:n tietokortti 7D14.

- 1976. Lihasian uudet viikottaiset ry-normit. Sika 1976, 3: 6-7.

Poutiainen, E. 1971. Tuoreena säilötyn ja kuivatun viljan vertailu broilerkokeissa. Koetoim. ja Kăyt. 28: $23-24$.

-, Korhonen, I., Tuori, M. \& Lampila, M. 1973. Eri menetelmillä tuoreena säilötty ohra lihanautojen rehuna. 1. Lisäaineiden vertailu märkăsăilönnässă. Kehittyvä Maatalous 15: 19-31.

Prigge, E.C., Johnson, R.R., Owens, F.N. \& WILLIAMS, D.E. 1976. Soluble nitrogen and acid production of high moisture corn. Anim. Sci. 42: 490-496.

Pringle, D., Beames, R.M., Tait, R.M. \& Litsky, J. 1983. Effect of storage and processing of barley by pigs and rats. Anim. Feed. Sci. \& Technol. 9: 89-97.

Roth, F.X. \& Kirchgessner, M. 1984. Verdaulichkeit der Energie und Rohnährstoffe. Z. Tierphysiol. Tierernähr. u. Futtermittelkde. 51: 79-87.

SALO, M-L. 1978. Puumelassi tuoreen viljan säilöntäaineena. J. Scient. Soc. Agric. Soc. Finl. 50: 206-211.

— \& SAlmi, M. 1968. Determination of starch by amyloglucosidase method. J. Scient. Agric. Soc. Finl. 40: $38-45$.

-, Huhtanen, P. \& Virtanen, E. 1981. Sulfiittisellu- loosateollisuuden sivutuotteet tuoreviljan säilöntäaineena. Koetoim. ja Käyt. 1981: 24.

-, TUORI, M. \& KIISKINEN, T. 1982. Rehutaulukot ja ruokintanormit. 70 p. Helsinki.

Schmidt, L., Weissbach, F. \& Petters, G. 1978. Harnstoff als Konservierungsmittel bei der Lagerung von Feuchtgetreide. 1. Mitteilung. Konservierung von Feuchtgetreide. Arch. Tierernähr. 28: 123-129.

TAUSSKY, H.H. \& SHORR, E. 1953. A microcolorimetric method for the determination of inorganic phosphorus. J. Biol. Chem. 202: 675-685.

Тномке, S. 1968. Einfluss der Wassergehaltes und des Zerkleinerungsgrades auf die Verdaulichkeit silierten Getreide bei Schweinen. Das wirtschaftseigene Futter 15: 93-101.

— \& TIDEN, A. 1973. Moist barley treated with propionic, acetic and formic acid in rations to growing pigs. Swed. J. agric. Res. 3: 145-151.

Thornton, J.H., Owens, F.N., Williams, D.E. \& ArNOLD, M. 1977. Chemical characterization of ensiled high moisture corn grain. Okla. Agr. Exp. Sta. MP-101: 56-62.

Thyselıus, L. 1971. Kemiska och mikrobiologiska förăndringar vid spannmålsensilering. JTI Specialmeddelande S21: $1-45$.

Weissbach, F. \& Schadereit, R. 1968. Untersuchungen zur Konservierung von Feuchtgetreide durch Silierung. 2. Mitteilung. Verdauugsversuche mit Silagen aus Feuchtgetreide. Arch. Tierernähr. 18: 61-67.

Ms received October 12, 1984 


\section{SELOSTUS}

\section{Puumelassi tuoreen ohran säilöntäaineena.}

\section{Säilöntäkokeet ja sulavuus sioilla}

\section{Pekka Huhtanen}

Helsingin yliopisto, Kotieläintieteen laitos, 00710 Helsinki 71

Kahdessa kokeessa selvitettiin sulfiittijäteliemestä valmistetun puumelassin soveltuvuutta rehuviljan murskesăilöntäăn. Kokeessa 1 puumelassin annostelutaso oli 8 ja $16 \%$ ohran kuiva-aineesta. Kokeessa 2 annostelutaso oli vastaavasti $12 \%$ ja vertailuna käytetyn AIV IIliuoksen 3 1/1000 kg. Säilötyn viljan kuiva-ainepitoisuus oli kokeessa 1 noin $55 \%$ ja kokeessa $255-60 \%$. Sulavuus- ja tasekokeessa $31-86 \mathrm{~kg}$ :n painoisilla lihasioilla verrattiin kuivatun, propionihapolla jyväsäilötyn ja AIV II-liuoksella tai puumelassilla murskesảilötyn ohran sulavuutta sekä vaikutusta typen hyväksikäyttöön.

Kokeessa $18 \%$ :n annostelutaso osoittautui riittāväksi. Puumelassin vaikutus perustui päảasiassa sen sisăltămien orgaanisten happojen aiheuttamaan happamuuteen. Maitohappopitoisuus oli $16 \%$ :n annostelutasolla alempi $(\mathrm{P}<0.05)$. Kokeen 2 voimakkaammin neutraloitu puumelassi aiheutti voimakkaan maitohappokäymisen. Puumelassilla săilötyn ohran maito- ja etikka- happopitoisuus olivat korkeammat $(\mathrm{P}<0.05)$ ja $\mathrm{pH}$ alempi $(\mathrm{P}<0.05)$ kuin AIV II-liuoksella săilötyn. Puumelassi văhensi valkuaisen pilkkoutumista săilönnăn aikana. Viljan kosteuspitoisuuden vaikutus käymiseen ja valkuaisaineiden hajoamiseen oli AIV II-liuoksella säilötyssă viljassa suurempi. Murskesäilönnässă osa viljan tărkkelyksestä hydrolysoitui sokeriksi.

AIV II-liuoksella ja puumelassilla murskesăilötyn ohran kuiva-aineen, orgaanisen aineen, typettömien uuteaineiden ja tärkkelyksen sulavuudet olivat merkitsevăsti $(\mathrm{P}<0.05)$ huonommat kuin kuivatulla ohralla. Dieetin orgaanisen aineen sulavuudet olivat $82.2,81.0$ ja $85.4 \%$. Osaltaan murskesảilötyn ohran huonompi sulavuus johtui viljan epătăydellisestä litistyksestă. Propionihapolla säilötyn ohran sulavuus oli hieman huonompi kuin kuivatun. Typpitaseessa ei ollut merkitseviă eroja ruokintojen vălillä. 